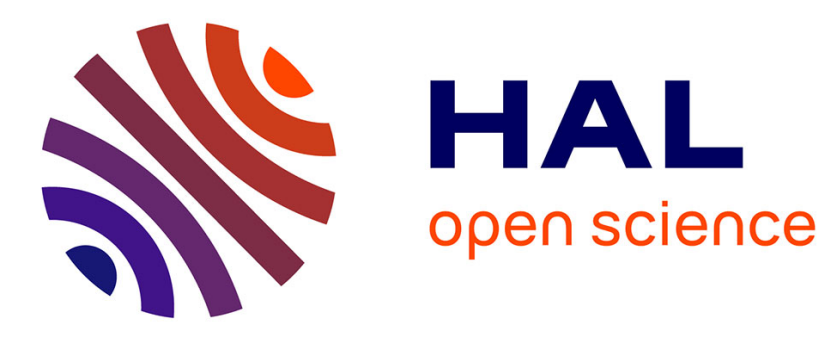

\title{
Ivermectin induces P-glycoprotein expression and function through mRNA stabilization in murine hepatocyte cell line
}

Cécile Menez-Berlioz, Laila Mselli-Lakhal, Magali Vignault-Foucaud, Patrick Balaguer, Roger Alvinerie, Anne Lespine

\section{To cite this version:}

Cécile Menez-Berlioz, Laila Mselli-Lakhal, Magali Vignault-Foucaud, Patrick Balaguer, Roger Alvinerie, et al.. Ivermectin induces P-glycoprotein expression and function through mRNA stabilization in murine hepatocyte cell line. Biochemical Pharmacology, 2012, 83 (2), pp.269-278. 10.1016/j.bcp.2011.10.010 . hal-01191347

\section{HAL Id: hal-01191347 \\ https://hal.science/hal-01191347}

Submitted on 1 Sep 2015

HAL is a multi-disciplinary open access archive for the deposit and dissemination of scientific research documents, whether they are published or not. The documents may come from teaching and research institutions in France or abroad, or from public or private research centers.
L'archive ouverte pluridisciplinaire HAL, est destinée au dépôt et à la diffusion de documents scientifiques de niveau recherche, publiés ou non, émanant des établissements d'enseignement et de recherche français ou étrangers, des laboratoires publics ou privés. 


\title{
Ivermectin induces P-glycoprotein expression and function through mRNA stabilization in murine hepatocyte cell line
}

\author{
Cécile Ménez $^{\text {a,* }}$, Laïla Mselli-Lakhal ${ }^{a}$, Magali Foucaud-Vignault ${ }^{a}$, Patrick Balaguer ${ }^{\text {b,c,d,e }}$, \\ Michel Alvinerie ${ }^{\mathrm{a}}$, Anne Lespine ${ }^{\mathrm{a}}$ \\ a INRA UMR1331, Université de Toulouse, INP, TOXALIM, Toulouse, F-31027, France \\ ${ }^{\mathrm{b}}$ IRCM, Institut de Recherche en Cancérologie de Montpellier, Montpellier, F-34298, France \\ ' INSERM, U896, Montpellier, F-34298, France \\ d Université Montpellier1, Montpellier, F-34298, France

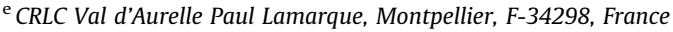

\section{A R T I C L E I N F O}

\section{Article history:}

Received 29 August 2011

Accepted 11 October 2011

Available online 18 October 2011

\section{Keywords:}

Ivermectin

Macrocyclic lactones

P-glycoprotein

Mdr1

Hepatocytes

\begin{abstract}
A B S T R A C T
Ivermectin is widely used in human and veterinary medicine for the control of helminth infections. Ivermectin is known to interact with P-glycoprotein (P-gp/MDR1), being a good substrate and a potent inhibitor, however, the influence of ivermectin on the expression of the transporter has not been investigated. Expression of P-glycoprotein was investigated in cultured mouse hepatocytes acutely exposed to ivermectin. The two P-glycoprotein murine isoforms, Mdr1a and Mdr1b, mRNA levels were assessed by real-time RT-PCR. Ivermectin induced a clear time- and concentration-dependent upregulation of Mdr1a and Mdr1b mRNA levels (as early as a 12-h exposure and up to 2.5-fold at $10 \mu \mathrm{M}$ ). Moreover, ivermectin-treated cells displayed enhanced cellular efflux of the P-glycoprotein substrate calcein that was inhibited by the P-glycoprotein blocker valspodar, providing evidence that the ivermectin-induced P-glycoprotein was functional. The mechanisms underlying these effects were investigated. Ivermectin-mediated Mdr1 mRNA induction was independent of the two nuclear receptors CAR and PXR, which are known to be involved in drug transporters regulation. Moreover, by using reporter cell lines that detects specific ligand-activated transcription factors, we showed that ivermectin did not displayed CAR, PXR or AhR ligand activities. However, studies with actinomycin D revealed that the half-life of Mdr1a and Mdr1b mRNA were significantly prolonged by two-fold in ivermectin-treated cells suggesting a post-transcriptional mode of ivermectin regulation. This study demonstrates for the first time that ivermectin induces P-glycoprotein overexpression through post-transcriptional mRNA stabilization, thus offering insight into the mechanism of reduced therapeutic efficacy and development of ivermectin-resistant parasites.
\end{abstract}

(c) 2011 Elsevier Inc. All rights reserved.

\section{Introduction}

Macrocyclic lactones (MLs), such as ivermectin, are a large family of broad spectrum antiparasitic drugs intensively used worldwide in livestock to treat diseases caused by gastrointestinal nematodes and external parasites. In humans, ivermectin is used through mass drug administration programs for the treatment of onchocerciasis, a tropical parasitic disease caused by the filarial nematode Onchocerca volvulus. MLs resistance has become a

\footnotetext{
Abbreviations: ABC, ATP-binding cassette; AhR, aryl-hydrocarbon receptor; CAR, constitutive androstane receptor; IVM, ivermectin; MLs, macrocyclic lactones; Pgp, P-glycoprotein; PXR, pregnane X receptor.

* Corresponding author at: INRA ToxAlim - UMR 1331 INRA/INP, 180 chemin de Tournefeuille - BP 93173, 31027 Toulouse Cedex 3, France. Tel.: +33 561285152; fax: +33561285310 .

E-mail address: cecile.menez@toulouse.inra.fr (C. Ménez).
}

worsening problem in veterinary medicine and recent reports suggest that human ivermectin-resistant parasites are emerging, thus threatening the sustainable efficacy of this drug [1].

P-glycoprotein (P-gp, MDR1/ABCB1) is a plasma membrane protein belonging to the ATP-binding cassette $(A B C)$ transporters family. This transporter is an ATP-dependent efflux pump that reduces the intracellular concentration of a broad range of hydrophobic compounds and is involved in the multidrug resistance (MDR) [2]. The activity of efflux $A B C$ transporters can be subject to regulation by inhibition or induction and considerable evidence has accumulated to indicate that $M D R$ gene expression can be rapidly and transiently induced following acute exposure to some xenobiotics [3,4]. The regulation of $A B C$ transporters occurs by transcriptional or post-transcriptional events. At transcriptional level, the constitutive androstane receptor (CAR, NR1I3) and the pregnane $X$ receptor (PXR, SXR, NR1I2), two nuclear receptors primarily expressed in the liver, are 
now both widely recognized to play the most important role in the regulation of MDR1 [5-7]. Other specific ligand-activated transcription factors have been implicated in regulation of drug transporters expression such as aryl-hydrocarbon receptor (AhR) [8]. Apart from transcriptional regulation, overexpression of P-gp has also been shown to be controlled partially through posttranscriptional mechanisms, such as mRNA stability alteration $[9,10]$.

P-gp has been clearly identified as the main factor that controls the concentration of ivermectin by affecting its absorption, distribution, and elimination in the host $[11,12]$, but also its neurotoxicity by limiting its penetration in the brain [13]. Despite the key role of P-gp in metabolism, toxicity, efficacy and drug-drug interactions of many other xenobiotics [14], the question of whether ivermectin can affect the expression levels of P-gp has not been addressed. Several arguments from the literature imply that ivermectin may modulate P-gp expression. (i) Many P-gp function modulators are often found to influence the expression of the transporter in cells [15], and ivermectin is reported as good substrate and potent inhibitor of P-gp [16,17]. (ii) Ivermectin was previously shown to induce the expression and activity of cytochrome P450 isoenzymes, including CYP1A, 2B and 3A subfamilies in vivo $[18,19]$, suggesting that ivermectin could interact with cellular transcription factors such as AhR, CAR and PXR which are involved in chemical induction of these cytochromes [20]. Since several studies have shown that the biotransformation systems (phase I/II) and efflux proteins are regulated by the same network of transcription factors, one can speculate that ivermectin may also regulate $A B C$ efflux transporters expression. (iii) P-gp homologs expression levels were shown to be increased in ivermectin-resistant nematodes [21-23].

In this context, this study aimed at investigating $\mathrm{P}$-gp regulation in response to acute ivermectin treatment. Hepatocytes were chosen as a suitable in vitro model system for studying the potential of xenobiotics to modulate P-gp gene expression [24] and elucidating the role of specific transcription factors in the regulation of gene involved in the metabolism of xenobiotics $[25,26]$. The objectives were to evaluate the ability of ivermectin to modulate P-gp gene expression, to determine the functional significance of this modulation and to further establish molecular mechanisms underlying this effect. Our finding demonstrate for the first time that acute exposure to ivermectin led to overexpression of functional P-gp in mouse liver cells through increased stability of mRNA in the cell.

\section{Materials and methods}

\subsection{Materials}

1,4-Bis[2-(3,5-dichloropyridyloxy)] benzene (ТСРОВОР), pregnenolone $16 \alpha$-carbonitrile (PCN), dimethylsulfoxide (DMSO), T0901317, geneticin (G418), Triton X-100, calcein-AM, actinomycin D (Act-D) and ivermectin were purchased from Sigma-Aldrich Chimie (St Quentin Fallavier, France). Luciferin was from Promega (Charbonnières-les-bains, France). Valspodar (VP) was a generous gift from Novartis (Basel, Switzerland). 2,3,7,8-Tetrachlorodibenzo-p-dioxin (TCDD, dioxin) was purchased from Promochem (Wesel, Germany). Dulbecco's modified Eagle's medium (DMEM), phosphate buffered saline (PBS), fetal bovine serum (FBS), glutamine, penicillin-streptomycin solution (10,000 units/ml penicillin and $10,000 \mu \mathrm{g} / \mathrm{ml}$ of streptomycin), trypsin-EDTA solution (0.05\% trypsin, $0.53 \mathrm{mM}$ EDTA) and lipofectamine 2000 were obtained from Invitrogen - Life Technologies (Cergy Pontoise, France). Tissue culture plastic flasks and culture plates were supplied by Sarstedt (Orsay, France). All other chemicals were obtained from Sigma-Aldrich, unless otherwise stated.

\subsection{Cell culture and treatment}

JWZ murine hepatic cells, also referred to as MuSH immortalized hepatocytes [27], were kindly provided by Dr. J.P. Gray (Pennsylvania, USA). These cells expressed standard levels of Retinoid X Receptor (RXR), the heterodimeric partner of the nuclear receptors CAR and PXR, while CAR and PXR transcript are barely detectable, providing a useful tool for mechanistic examination of the role of nuclear receptors in gene regulation, as previously described $[27,28]$. JWZ cells were cultured in DMEM supplemented with $10 \%$ fetal bovine serum, $2 \mathrm{mM}$ L-glutamine and $100 \mathrm{U} / \mathrm{ml}$ penicillin, $100 \mu \mathrm{g} / \mathrm{ml}$ streptomycin. Cells were kept at $34{ }^{\circ} \mathrm{C}$ in $5 \% \mathrm{CO}_{2}$ and $95 \%$ humidity. Every 3-4 days, cells were trypsinized and seeded at $5 \times 10^{5}$ cells per 6 -well cluster trays for induction studies. The cells were grown at more than $80 \%$ confluence and exposed to ivermectin or different compounds of interest at various concentrations or to the vehicle for $6,12,24,48$ or $72 \mathrm{~h}$. All drugs were dissolved in DMSO at a final concentration of $0.1 \%(\mathrm{v} / \mathrm{v})$.

\subsection{Cytotoxicity assays}

\subsubsection{Cell viability: the MTS-tetrazolium salt assay}

The cell viability in presence of ivermectin was evaluated using the CellTiter $96{ }^{\mathbb{R}} \mathrm{AQ}_{\text {ueous }}$ Non-Radioactive Cell Proliferation Assay (Promega, Charbonnières-les-bains, France). The MTS (3-(4,5dimethylthiazol-2-yl)-5-(3-carboxymethoxyphenyl)-2-(4-sulfophenyl)-2H-tetrazolium) assay is based on the ability of viable cells to convert a soluble tetrazolium salt to a formazan product. JWZ cells were seeded at $5 \times 10^{4}$ cells in 96-well culture plates. $24 \mathrm{~h}$ after seeding, increasing concentrations of ivermectin were added; media and DMSO were used as negative and positive controls, respectively. JWZ cells were further incubated at $34^{\circ} \mathrm{C}$ for 24,48 or $72 \mathrm{~h}$. Thereafter, $20 \mu \mathrm{l}$ of the MTS/PMS mixture (MTS/PMS ratio: 20:1) was added to each well and plates were incubated at $34^{\circ} \mathrm{C}$ for $4 \mathrm{~h}$. At the end of incubation period, absorbance was recorded at $492 \mathrm{~nm}$ using a multiwell-scanning spectrophotometer.

\subsubsection{Release of lactate dehydrogenase}

The effect of ivermectin upon cell integrity was also determined by measurement of lactate dehydrogenase (LDH)-release as a marker of cell membrane damage using the Cytotoxicity Detection Kit (Roche Applied Science, Meylan, France). JWZ cells grown on 96-well dishes were incubated with increasing concentrations of ivermectin. After 24,48 or $72 \mathrm{~h}$ of exposure $100 \mu \mathrm{l}$ samples were withdrawn and analyzed for LDH content. In control experiments, cells were incubated with medium or $1 \%$ Triton X-100. Afterwards, results were normalized to $0 \%$ and $100 \% \mathrm{LDH}$ release, respectively.

\subsection{Functional detection of the P-gp activity (calcein assay)}

P-glycoprotein transport activity was assessed following the intracellular accumulation of the P-gp fluorescent substrate calcein, as previously described [29]. Briefly, confluent JWZ cells in 24-well cluster plates were cultured with (treated cells) or without (control cells) $10 \mu \mathrm{M}$ ivermectin for $48 \mathrm{~h}$. Cells were then incubated with or without the reference P-gp inhibitor valspodar $(5 \mu \mathrm{M})$ for $40 \mathrm{~min}$. After this pre-incubation period, cells were washed with PBS buffer and $0.5 \mu \mathrm{M}$ calcein-AM (in DMSO) was added for a 2-h incubation period at $34^{\circ} \mathrm{C}$. Medium was then removed, cells were washed 2 times with ice-cold PBS and a lysis buffer (1\% Triton X-100 and SDS $0.1 \%$ in PBS) was added. The intracellular fluorescence corresponding to calcein accumulation was measured in cell lysate by using a microplate reader (TECAN, Infinite ${ }^{\mathrm{TM}} 200$, Lyon, France), with a $485 \mathrm{~nm}$ excitation wavelength and $530 \mathrm{~nm}$ emission filter. Values were normalized to the protein 
content per well determined by using a Bio-Rad protein assay kit (Bio-Rad Laboratories, Marnes-la-Coquette, France).

\subsection{Total RNA isolation and RT-PCR analysis}

\subsubsection{Isolation of RNA and CDNA synthesis}

After two washes with ice-cold PBS, the cells were harvested and total cellular RNA was isolated using Trizol Reagent (Invitrogen, Cergy Pontoise, France) according to the manufacturer's instructions. Total RNA was quantified using nanodrop ND-1000 spectrophotometer (Nanodrop Technologies Inc., Wilmington, DE, USA). RNA purity was checked by measurement of the $A_{260 / 280} \mathrm{~nm}$ ratio, which was routinely in the range of $1.8-2.0$, and RNA integrity was checked upon migration in 1\% agarose gel and visualization with ethidium bromide staining and UV irradiation. cDNA was synthesized from $2 \mu \mathrm{g}$ of total RNA using the HighCapacity cDNA Reverse Transcription kit (Applied Biosystems Life Technologies, Courtaboeuf, France).

\subsubsection{Quantification of $m R N A$ expression by RT-PCR}

Real-time quantitative PCR (RT-qPCR) was performed using an ABI Prism 7300 Sequence Detection System instrument and software (Applied Biosystems, Courtaboeuf, France). Genespecific primers for SYBR Green assays are described in Table 1. All primers were designed using Primer Express software version 2.0 (Applied Biosystems) and synthesized by Invitrogen (Cergy Pontoise, France). All primers were entered into the NCBI Blast program to ensure specificity. Results were expressed using the comparative $\mathrm{Ct}$ method as described in User Bulletin 2 (Applied Biosystem). Briefly, the $\Delta C_{\mathrm{t}}$ values were calculated in every sample for each gene of interest as following: $C_{\mathrm{t}}$ gene of interest $-C_{t}$ reporter gene, with TATA-box binding protein (TBP) as the reporter gene. The fold change in the level of target $m R N A$ between treated and untreated cells was then expressed as $2^{-\Delta C_{t}}$ with $\Delta C_{\mathrm{t}} \pm$ S.D. where S.D. is the standard deviation of the mean of the $\Delta C_{\mathrm{t}}$ value. A dissociation curve allowed us to verify the specificity of the amplification.

\subsection{Transient transfection assay and DNA constructs}

The pCR3-mCAR construct expressing the murine CAR was kindly provided by Dr. M. Negishi (North Carolina, USA) and the pSG5-mPXR construct expressing the murine PXR was kindly provided by Dr. J.M. Pascussi (Montpellier, France). These plasmids were described previously [28,30]. JWZ cells $\left(1.5 \times 10^{6}\right)$ were plated onto $10-\mathrm{cm}$ culture dishes and grown in DMEM supplemented with $10 \%$ fetal bovine serum, $2 \mathrm{mM} \mathrm{L-}$ glutamine, $100 \mathrm{U} / \mathrm{ml}$ penicillin, $100 \mu \mathrm{g} / \mathrm{ml}$ streptomycin in a $5 \%$ $\mathrm{CO}_{2}$ atmosphere at $34^{\circ} \mathrm{C} .24 \mathrm{~h}$ after seeding, cells were transiently transfected with $8 \mu \mathrm{g} /$ plate of plasmid construct containing the cDNA for mouse CAR (pCR3-mCAR), mouse PXR (pSG5-mPXR), or their control expression vector ( $\mathrm{pCR} 3$ or pSG5), using lipofectamine 2000 according to the manufacturer's protocol. Cells were transferred to 6 -well plates at a density of $5 \times 10^{5}$ cells/well $16 \mathrm{~h}$ after transfection. Drug treatments were performed $24 \mathrm{~h}$ after transfection.

\subsection{Study of the CAR-, PXR- and AhR-activating capacity of} ivermectin

\subsubsection{Stable reporter cell lines}

$\mathrm{HG}_{5} \mathrm{LN}$ parental cells, obtained by integration of GAL4RE $5_{5}$ $\beta$ Glob-Luc-SVNeo in HeLa cells and containing a stably integrated GAL4-responsive gene, have already been described [31]. mCARand mPXR-expressing cells were obtained, as previously described [32,33], by transfecting $\mathrm{HG}_{5} \mathrm{LN}$ cells with pSG5-GAL4(DBD)mPXR(LBD)-puro or pSG5-GAL4(DBD)-mCAR(LBD)-puro, which enables the expression of the DNA binding domain of the DNA binding domain of the yeast activator GAL4 (Met1-Ser147) fused to the ligand binding domain of MCAR or mPXR and confers resistance to puromycin. The rodent AhR-activating capacity was assessed with the H4IIE XRE-LUC cell line, which was obtained by transfecting rat H4IIE hepatocytes cells with CYP1A1-Luc and pSG5-puro plasmids. A similar dioxin reporter cell line, HAhLP, used to assess interactions with human AhR, has previously been described [34].

\subsubsection{Cell culture conditions}

$\mathrm{HG}_{5} \mathrm{LN}-\mathrm{mCAR}, \mathrm{HG}_{5} \mathrm{LN}-\mathrm{mPXR}$ and H4IIE XRE-LUC cell lines were cultured in DMEM F12, supplemented with $5 \%$ of fetal calf serum (FCS) and $1 \%$ antibiotic (penicillin/streptomycin) in a $5 \% \mathrm{CO}_{2}$ and $95 \%$ air-humidified atmosphere at $37^{\circ} \mathrm{C}$. $\mathrm{HG}_{5} \mathrm{LN}$ cell medium was supplemented with $1 \mathrm{mg} / \mathrm{ml}$ geneticin (G418) and $\mathrm{HG}_{5} \mathrm{LN}-\mathrm{mPXR}$ and -mCAR cell medium with $1 \mathrm{mg} / \mathrm{ml}$ geneticin and $0.5 \mu \mathrm{g} / \mathrm{ml}$ puromycin. To test ivermectin for its MCAR-, MPXR- and rAhRactivating capacity, cells were grown in DMEM F12 supplemented with 5\% dextran-coated, charcoal-treated fetal calf serum (DCCFCS).

\subsubsection{Living cell luciferase assay}

Reporter cells were seeded at a density of $2.5 \times 10^{4}$ cells per well in 96-well white opaque tissue culture plates (Greiner, France) and grown in $150 \mu \mathrm{l}$ DCC-FCS. Ivermectin or the reference effector (agonist or antagonist) was added $24 \mathrm{~h}$ after seeding and the cells were then incubated for $24 \mathrm{~h}$ with the compounds. Various concentrations were tested through serial dilution using an automated workstation (biomek ${ }^{\circledR} 2000$, Beckman Coulter). To ensure $100 \%$ cell viability, ivermectin concentration range used was set from $10^{-8} \mathrm{M}$ to $3.3 \times 10^{-6} \mathrm{M}$. Each concentration was tested in quadruplicate in at least two experiments which included both negative (solvent) and positive (reference agonist or antagonist) controls. At the end of incubation, medium was removed and replaced with $0.3 \mathrm{mM}$ luciferin-containing culture medium. Intact living cell luminescence was measured for $2 \mathrm{~s}$ using a Microbeta Wallac luminometer. Results were expressed as a fold-induction of the basal luciferase activity measured in untreated cells, which was set to 1. Reference agonist ligand was used in $\mathrm{HG}_{5} \mathrm{LN}-\mathrm{mPXR}$ and H4IIE XRE-LUC cells (PCN $10 \mu \mathrm{M}$ and TCDD (dioxin) $10 \mathrm{nM}$, respectively). Due to the high constitutive activity of CAR in $\mathrm{HG}_{5} \mathrm{LN}-\mathrm{mCAR}$ cells, a reference antagonist ligand was used as control (T0901317 $10 \mu \mathrm{M})$. All effectors were dissolved in DMSO at $10 \mathrm{mM}$ and then diluted in culture medium.

Table 1

Primer sequences used in quantification of the gene expression by qRT-PCR.

\begin{tabular}{|c|c|c|}
\hline Targeted gene & Forward primer $\left(5^{\prime}\right.$ to $\left.3^{\prime}\right)$ & Reverse primer $\left(5^{\prime}\right.$ to $\left.3^{\prime}\right)$ \\
\hline $\operatorname{Mdr1a}(A b c b 1 a)$ & CATGACAGATAGCTTTGCAAGTGTAG & GGCAAACATGGCTCTTTTATCG \\
\hline$M d r 1 b(A b c b 1 b)$ & AAGCCAGTATTCTGCCAAGCAT & CTCCAGACTGCTGTTGCTGATG \\
\hline Сур3а11 & TCACACACACAGTTGTAGGCAGAA & GTTTACGAGTCCCATATCGGTAGAG \\
\hline Cyp2b10 & TTTCTGCCCTTCTCAACAGGAA & ATGGACGTGAAGAAAAGGAACAAC \\
\hline TBP & ACTTCGTGCAAGAAATGCTGAA & GCAGTTGTCCGTGGCTCTCT \\
\hline
\end{tabular}




\subsection{Determination of Mdr1 mRNAs stability}

The half-lives of Mdr1a and Mdr1b mRNA were determined by an Act-D chase assay, as previously described [35]. JWZ cells were pre-treated with ivermectin $(10 \mu \mathrm{M})$ or DMSO for $24 \mathrm{~h}$. Thereafter, the transcription inhibitor actinomycin $\mathrm{D}$ was added to inhibit further RNA synthesis. Act-D was used at a final concentration of $5 \mu \mathrm{g} / \mathrm{ml}$ for $1 \mathrm{~h}$, then, to avoid Act-D toxicity, medium was replaced and Act-D, in the presence or absence of ivermectin $10 \mu \mathrm{M}$, was added at a concentration of $1 \mu \mathrm{g} / \mathrm{ml}$ for the following $24 \mathrm{~h}$. Cells were harvested, at various times $(0,3,6$, 10 and $24 \mathrm{~h}$ ) after the addition of $1 \mu \mathrm{g} / \mathrm{ml}$ Act-D, total RNA was isolated and levels of Mdr1a and Mdr1b mRNAs were quantified by RT-qPCR as described above. TBP mRNA levels were also monitored as control. The data were represented as percentage decrease in mRNA levels versus time using a semilogarithmic scale. The mRNA half-life values were determined with the use of regression curves.

\subsection{Statistical analysis}

All experiments were conducted at least in triplicate and results are expressed as mean \pm standard deviation (S.D.). Statistical analysis was performed using one-way analysis of variance (ANOVA) with a Tukey post-test to compare the effect of ivermectin over control cells, while individual comparisons between pairs of data were performed using the Mann-Whitney test (GraphPad Instat, San Diego, CA, USA). Statistical significance was accepted as $p<0.05$.
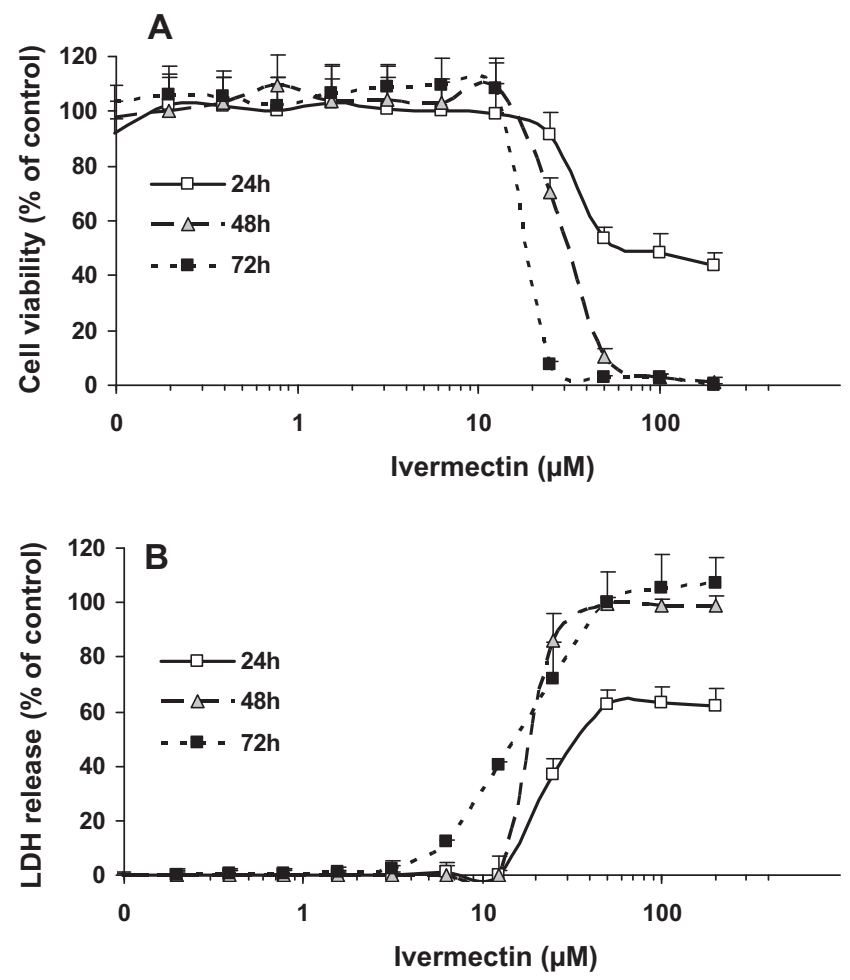

Fig. 1. Cytotoxic effects of ivermectin on JWZ cells as a function of time and concentration. Cytotoxicity was measured by the MTS assay (A) and LDH release (B) following 24,48 or $72 \mathrm{~h}$ incubation at $34{ }^{\circ} \mathrm{C}, 5 \% \mathrm{CO}_{2}$ and $95 \%$ relative humidity. For the MTS assay, medium and DMSO were used as positive ( $100 \%$ cell viability) and negative ( $0 \%$ cell viability) controls, respectively. For LDH assay, medium and Triton $1 \%$ were used as negative ( $0 \% \mathrm{LDH}$ release) and positive ( $100 \% \mathrm{LDH}$ release) controls, respectively, and results were normalized to $0 \%$ and $100 \% \mathrm{LDH}-$ release. All measurements were expressed as mean $\pm \operatorname{S.D}(n=8)$.

\section{Results}

\subsection{Effects of ivermectin on cell viability}

The aim of these studies was to determine subtoxic concentrations of ivermectin which could be used in the subsequent studies on hepatocytes JWZ cells. The cytotoxicity of ivermectin towards JWZ cells was examined using the MTS assay and LDH release. The dose-dependent viability of JWZ cells treated with ivermectin for 24,48 or $72 \mathrm{~h}$ is presented in Fig. 1. These results showed that ivermectin had cytotoxic effects in a concentration- and timedependent manner. A 24-h treatment with ivermectin up to $25 \mu \mathrm{M}$ induced no significant mitochondrial toxicity or cell-growth inhibition towards JWZ cells, as revealed by the MTS assay with more than 90\% cell viability; however LDH release around 35\% was observed. When JWZ cells were exposed to ivermectin for $72 \mathrm{~h}$ at concentration below $12.5 \mu \mathrm{M}$, no cytotoxic effects were observed. The effective $\mathrm{LD}_{50}$ values (concentration that causes $50 \%$ lethality) at 24,48 and $72 \mathrm{~h}$ were determined graphically and were approximately 75, 30 and $20 \mu \mathrm{M}$, respectively. Subsequent studies were performed following an ivermectin incubation period up to $72 \mathrm{~h}$ and with concentrations up to $10 \mu \mathrm{M}$, a time and concentration exposure of ivermectin that gave more than $80 \%$ cell viability and moderate LDH release (less than $20 \%$ ).

\subsection{Time-dependent effects of ivermectin on P-glycoprotein mRNA expression}

We first analyzed the effects of ivermectin treatment as a function of time on the expression of the 2 genes encoding the murine P-glycoprotein, Mdr1a and Mdr1b (Abcb1a and Abcb1b) in JWZ mouse cultured hepatocytes. JWZ cells were exposed to $10 \mu \mathrm{M}$ ivermectin for $6,12,24,48$, or $72 \mathrm{~h}$ and mRNA levels were determined by RT-qPCR. Fig. 2 shows a time-dependent upregulation in Mdr1a and Mdr1b mRNA when cells were exposed to $10 \mu \mathrm{M}$ ivermectin. A significant increase in mRNA level was

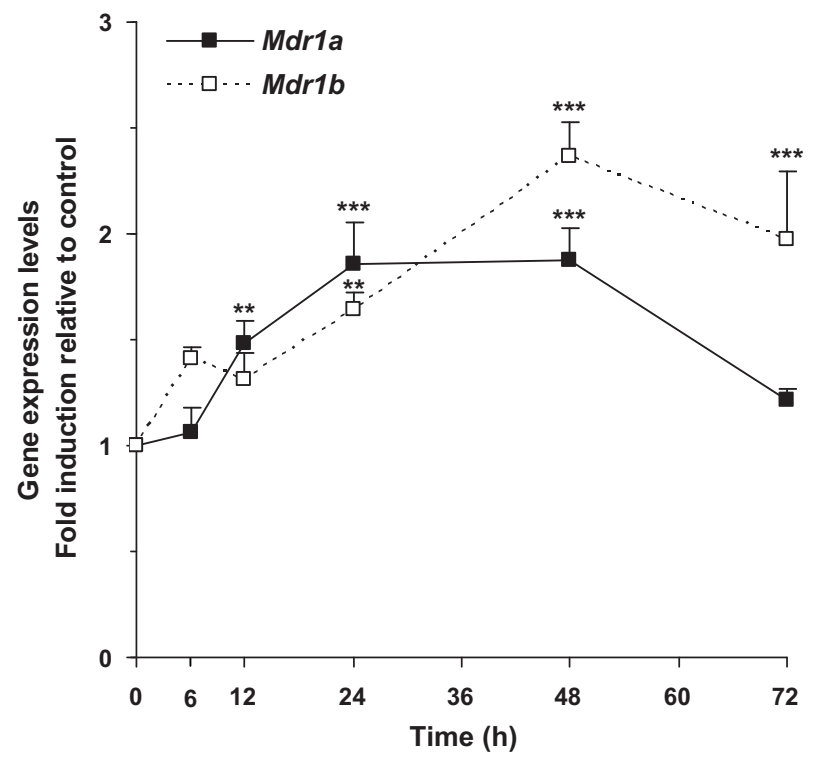

Fig. 2. Time-dependent effects of ivermectin on Mdr1a and Mdr1b mRNA levels. Mouse JWZ hepatocytes were treated with $10 \mu \mathrm{M}$ ivermectin (IVM) or with the vehicle alone (DMSO) for $6,12,24,48$ or $72 \mathrm{~h}$. Mdr1a and Mdr1b mRNA expression was then determined by real-time qPCR using gene-specific primers as described in Section 2. The mRNA expression levels were expressed as -fold increase over the corresponding control (untreated cells) given the arbitrary value of 1 . Data are reported as the mean \pm S.D. of three independent experiments. ${ }^{* *} p<0.01$; ${ }^{* * *} p<0.001$ versus untreated control. 
observed as early as $12 \mathrm{~h}$ after treatment for Mdr1a (1.5-fold, $p<0.01$ ) and $24 \mathrm{~h}$ for Mdr1b (1.6-fold, $p<0.01)$. The two Pglycoprotein mRNAs were maximally up-regulated after $48 \mathrm{~h}$ (1.9and 2.4-fold over control for Mdr1a and $M d r 1 b$, respectively). The up-regulation of Mdr1 expression appeared to be transient with a lower induction after a longer exposure to ivermectin (1.2- and 2.0-fold of control levels with a $72 \mathrm{~h}$ exposure for Mdr1a and $M d r 1 b$, respectively). TBP mRNA, which was used as a loading control, remained stable over the time period of the study (data not shown).

\subsection{Concentration-dependent effects of ivermectin on P-glycoprotein mRNA expression}

The dose-response relationship for ivermectin effects towards P-glycoprotein expression was then characterized. JWZ hepatocytes were either untreated or exposed to various concentration of ivermectin ranging from 0.5 to $10 \mu \mathrm{M}$ for $48 \mathrm{~h}$. Results are shown in Fig. 3. Even at low concentration such as $0.5 \mu \mathrm{M}$, ivermectin was able to alter the expression of Mdr1a with a slight but significant 1.3 -fold increase $(p<0.05)$. When higher concentrations were used, Mdr1 $a$ and Mdr1b mRNA levels were significantly increased by ivermectin treatment in a clear concentration-dependence manner up to 2.1- and 2.5-fold for Mdr1a and Mdr1b, respectively.

\subsection{P-glycoprotein functional activity in JWZ hepatocytes under influence of ivermectin}

We then determined whether the induction of $M d r 1$ gene expression by ivermectin resulted in a modulation of P-glycoprotein transport function. To measure P-gp transport activity in JWZ cells, we used a fluorometric assay previously described [29]. This assay utilizes lipophilic nonfluorescent calcein-AM which penetrates into the cell, where it is immediately cleaved by esterases to highly fluorescent calcein. Because calcein-AM is a high-affinity substrate for P-gp, intracellular calcein fluorescence inversely

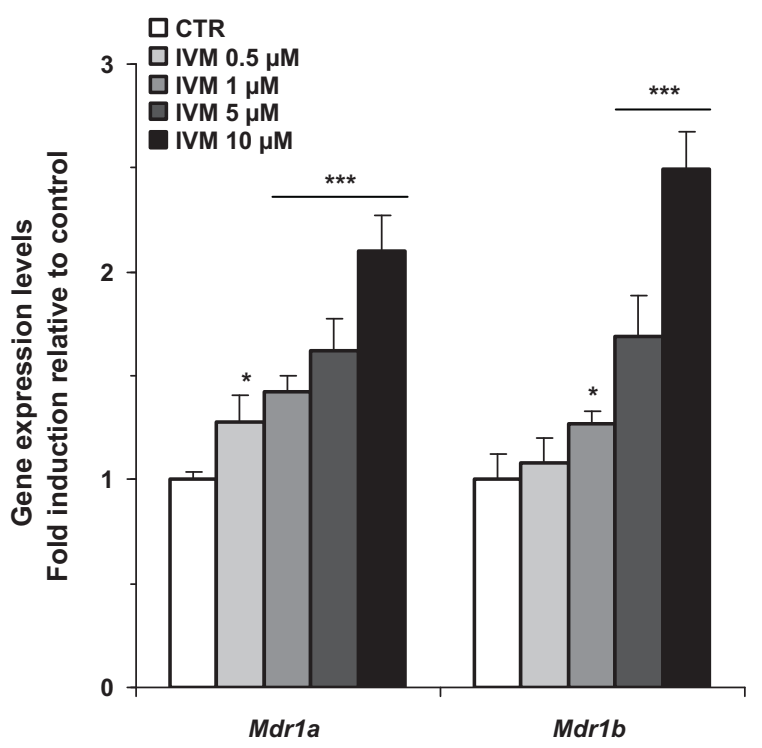

Fig. 3. Concentration-dependent effects of ivermectin on Mdr1a and Mdr1b mRNA levels. Mouse JWZ hepatocytes were either untreated (CTR) or exposed to increasing concentrations of ivermectin (IVM), ranging from 0.5 to $10 \mu \mathrm{M}$, for $48 \mathrm{~h}$. Changes in Mdr1a and Mdr1b mRNA levels, normalized with respect to TBP mRNA levels, were determined by real-time qPCR using gene-specific primers as described in Section 2. The mRNA expression levels were expressed as -fold induction relative to control (DMSO) and are reported as the mean \pm S.D. of six independent experiments. ${ }^{*} p<0.05 ;{ }^{* * *} p<0.001$ versus control. correlates with P-gp activity and, therefore, is a measure of P-gpmediated transport. Thus, an increase in P-gp activity results in reduced intracellular calcein fluorescence and vice versa.

As expected, the presence of valspodar, the P-glycoproteinselective blocker, in untreated cells resulted in a significant increase in calcein accumulation of more that 1.6-fold compared with control (Fig. 4). This result indicates that P-gp actively extruded calcein from JWZ cells and that valspodar clearly inhibit P-gp transport function in these cells. When JWZ cells were cultured with $10 \mu \mathrm{M}$ ivermectin for $48 \mathrm{~h}$ before measuring the intracellular calcein accumulation, a treatment which was shown to increase Mdr1 gene expression, intracellular calcein fluorescence was reduced by more than $30 \%$ compared with untreated cells, indicating that the P-gp-mediated efflux of calcein was increased. These results demonstrate that the induction of Mdr1 mRNA expression observed with $10 \mu \mathrm{M}$ ivermectin following a 48$\mathrm{h}$ exposure is associated with an increase in P-gp transport function. It is important to note that this effect was abolished with valspodar (Fig. 4), indicating that the reduction in intracellular calcein fluorescence was specifically mediated by P-gp.

\subsection{Role of transcription factors in the ivermectin-induced modulation of P-glycoprotein mRNA expression}

Because CAR, PXR and AhR have been recognized as transcription factors playing an important role in the xenobiotic-induced regulation of the expression of efflux $A B C$ transporters such as P-gp $[6,36,37]$, we investigated their role in the ivermectin-induced upregulation of Mdr1 mRNA expression through two different approaches.

\subsubsection{Induction of Mdr1a and Mdr1b mRNA by ivermectin in CAR-} and PXR-overexpressing cells

Nuclear receptors-overexpressing hepatocytes have proved to be useful models in elucidating the role of transcription factors in the induction of $A B C$ efflux transporters or cytochromes by xenobiotics $[25,26]$. We therefore firstly evaluated the effects of ivermectin in JWZ hepatocytes overexpressing the functional mouse CAR (Fig. 5A) or PXR (Fig. 5B). As previously described,

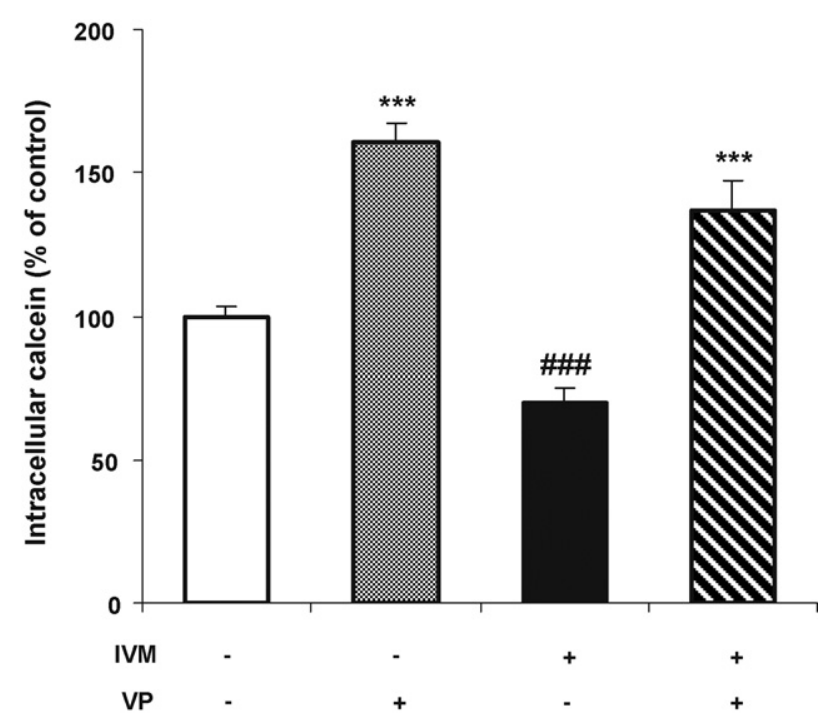

Fig. 4. P-glycoprotein transport activity in JWZ cells exposed to ivermectin. Intracellular calcein fluorescence was assessed in untreated cells or following a 48$\mathrm{h}$ treatment with ivermectin (IVM, $10 \mu \mathrm{M}$ ) with or without a 40 -min pre-exposure to the P-gp-specific inhibitor valspodar (VP, $5 \mu \mathrm{M})$. Data are expressed as percentage of control; each data represents mean \pm S.D. $(n=4) .{ }^{* * *} p<0.001$, significantly greater than control; ${ }^{\# \# \# ~} p<0.001$, significantly lower than control. 

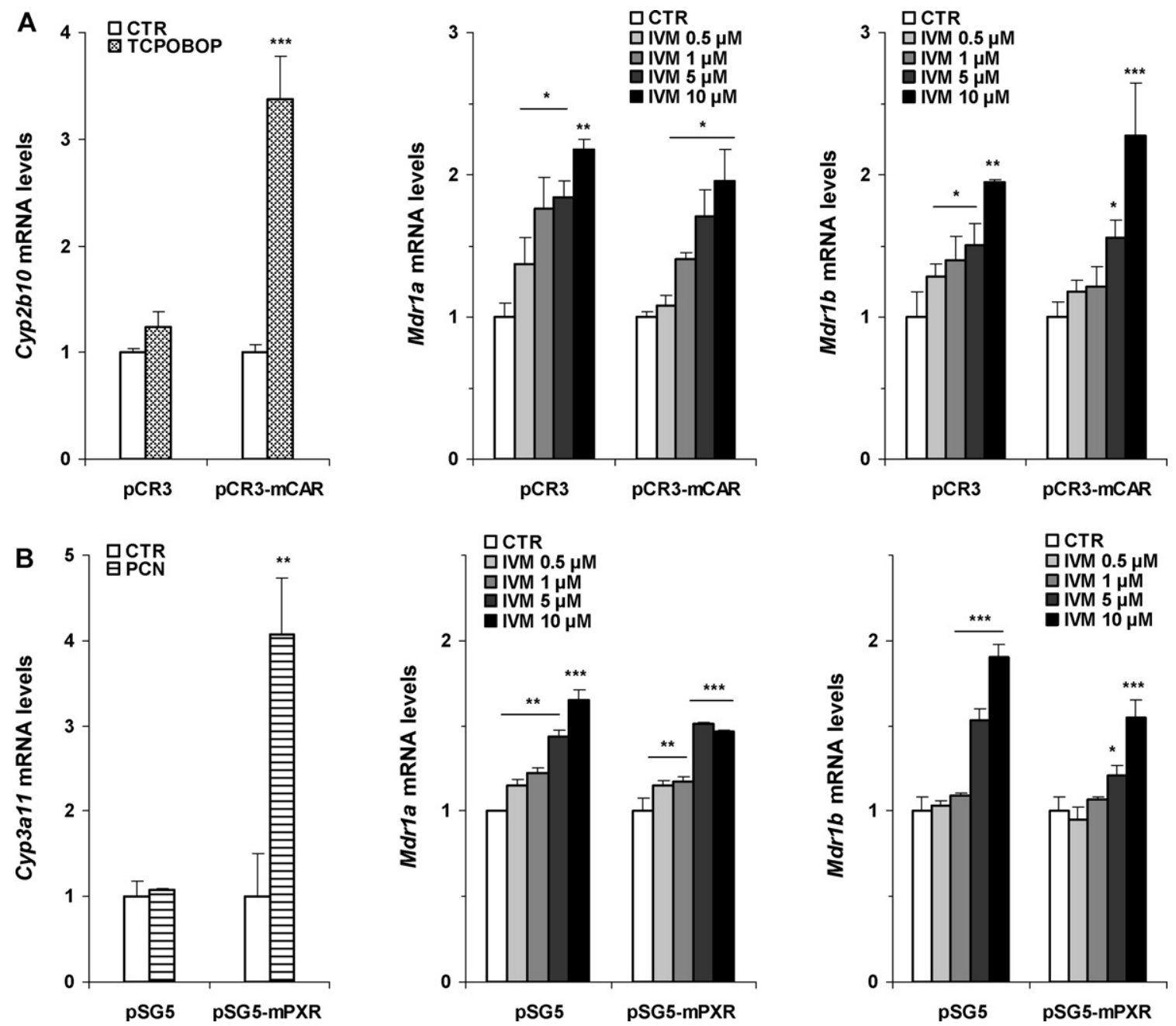

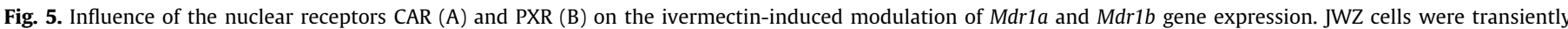

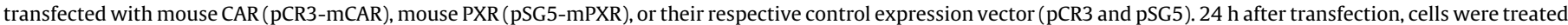

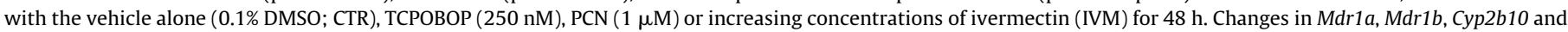

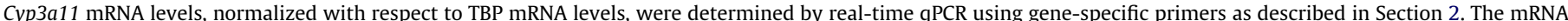
expression levels were expressed as -fold induction relative to control and are reported as the mean \pm S.D. $(n=6)$. ${ }^{*} p \leq 0.05 ;{ }^{* *} p \leq 0.01$; ${ }^{* * *} p \leq 0.001$ versus control.

Cyp2b10 and Cyp3a11, the prototypical target genes of CAR [38] and PXR [39], were used as a positive indicator for CAR or PXR activation, respectively; while TCPOBOP, a synthetic direct agonist of mouse CAR, and PCN, a synthetic agonist of mouse PXR, were used as positive controls.

In untransfected JWZ cells, mouse CAR and PXR constitutive expression levels were extremely low under basal conditions, which correlated with the impaired induction of Cyp $2 b 10$ by TCPOBOP or Cyp3a11 by PCN, respectively (Fig. 5). In JWZ cells transiently transfected with pmCAR or pmPXR, TCPOBOP or PCN were able to increase either Cyp2b10 (3.4-fold, $p<0.001$, Fig. $5 \mathrm{~A}$ ) or Cyp3a11 (4.1-fold, $p<0.001$, Fig. 5B) expression, demonstrating that these nuclear receptors could be further activated in our model by an agonist. Fig. 5 shows that a 48-h exposure of ivermectin modified the expression level of Mdr1a and Mdr1b in the exact same manner in CAR- or PXR-overexpressing cells compared with JWZ cells transfected with the control plasmid: the overexpression of these nuclear receptors did not further upregulate $M d r 1$ in ivermectin-treated cells and no significant differences in fold-induction levels were observed compared with control JWZ cells. These results provide support for the hypothesis that the ivermectin-induced regulations were independent of the activation of CAR or PXR nuclear receptors.

\subsubsection{Activation of PXR, CAR and AhR by ivermectin}

In order to provide more data on the capacity of ivermectin to activate specific transcription factors, we used bioluminescent reporter cell lines which have already proved to be a valuable model to detect nuclear receptor ligands $[31,40]$. These cells expressed the GAL4-DNA binding domain fused to different nuclear receptor ligand binding domains and allow the detection of compounds that activate some specific transcription factors.

Ivermectin was tested for its ability to activate rodent transcription factors (murine CAR, murine PXR and rat AhR) by using three different reporter cell lines $\left(\mathrm{HG}_{5} \mathrm{LN}-\mathrm{mCAR}, \mathrm{HG}_{5} \mathrm{LN}\right.$ MPXR and H4IIE XRE-LUC) in which PXR, CAR and AhR agonists or antagonists induced or repressed luciferase gene expression. Activation was measured in these cells in the presence of increased concentrations of ivermectin from $10^{-8} \mathrm{M}$ to $3.3 \times 10^{-6} \mathrm{M}$. The vehicle alone (DMSO) was used as negative control (luciferase activity baseline set to 1) and known reference effectors were used as positive control, as already described [34]. Results are presented in Table 2. As expected, the basal luciferase activity of the MPXR and rAhR cell lines after treatment with their reference agonist was increased (2.3- and 10.1-fold, respectively) and the luciferase activity of the mCAR cell line was significantly decreased for more than fourfold after treatment with the antagonist ligand T0901317 
Table 2

Modulation of luciferase expression by ivermectin in stable transfected cells.

\begin{tabular}{|c|c|c|c|c|c|c|c|c|c|}
\hline \multirow[t]{3}{*}{ Cell lines } & \multirow[t]{3}{*}{ Transcription factor } & \multicolumn{8}{|c|}{ Luciferase activity (fold induction to CTR) } \\
\hline & & \multirow[t]{2}{*}{ CTR (DMSO) } & \multicolumn{6}{|c|}{ IVM concentration } & \multirow[t]{2}{*}{ Reference effector } \\
\hline & & & $10^{-8} \mathrm{M}$ & $3.3 \times 10^{-8} \mathrm{M}$ & $10^{-7} \mathrm{M}$ & $3.3 \times 10^{-7} \mathrm{M}$ & $10^{-6} \mathrm{M}$ & $3.3 \times 10^{-6} \mathrm{M}$ & \\
\hline $\mathrm{HG}_{5} \mathrm{LN}-\mathrm{mCAR}$ & mCAR & $1.00 \pm 0.05$ & $1.03 \pm 0.07$ & nd & $1.05 \pm 0.05$ & nd & $1.04 \pm 0.05$ & nd & $\begin{array}{l}\text { T0901317 } 10 \mu \mathrm{M} \\
\text { (reference antagoniste) } \\
0.24 \pm 0.02^{* * *}\end{array}$ \\
\hline $\mathrm{HG}_{5} \mathrm{LN}-\mathrm{mPXR}$ & mPXR & $1.00 \pm 0.03$ & $1.02 \pm 0.03$ & nd & $1.04 \pm 0.03$ & nd & $1.03 \pm 0.03$ & nd & $\begin{array}{l}\text { PCN } 10 \mu \mathrm{M} \\
\text { (reference agoniste) } \\
2.33 \pm 0.05^{* * *}\end{array}$ \\
\hline H42E XRE & rAhR & $1.00 \pm 0.15$ & $1.09 \pm 0.07$ & $1.03 \pm 0.01$ & $1.12 \pm 0.20$ & $1.15 \pm 0.11$ & $1.05 \pm 0.05$ & $1.07 \pm 0.12$ & $\begin{array}{l}\text { TCDD (dioxin) } 10 \mathrm{nM} \\
\text { (reference agoniste) } \\
10.83 \pm 0.86^{* * *}\end{array}$ \\
\hline
\end{tabular}

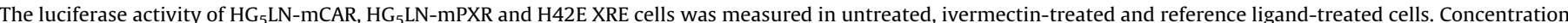

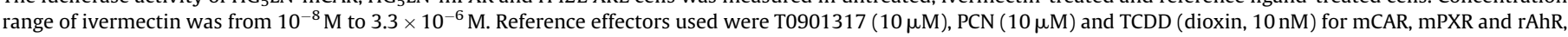

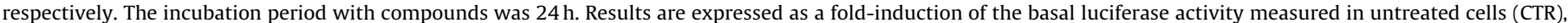
which was set to 1 , and are presented as mean \pm S.D. (quadruplet). ${ }^{* *} p<0.001$ versus control. nd: not determined; m: murine; and $r$ : rat.

(Table 2). Ivermectin, at all concentrations tested, did not modulated luciferase gene expression in $\mathrm{HG}_{5} \mathrm{LN}-\mathrm{mCAR}, \mathrm{HG}_{5} \mathrm{LN}-$ MPXR or H4IIE XRE-LUC cell lines (Table 2): the activation in ivermectin-treated cells was not statistically different from untreated cells. These results showed that ivermectin was not a CAR, PXR or AhR ligand.

\subsection{Effect of ivermectin on Mdr1a and Mdr1b mRNA stability}

The level of mRNA expression is the result of the balance between the transcription and the elimination rate, through processing and degradation. The absence of influence of CAR and PXR on ivermectin-induced up-regulation of P-glycoprotein encoding genes prompted us to study the effect of ivermectin on Mdr1a and Mdr1b mRNA stability. Therefore, the half-lives of Mdr1 mRNA in control and ivermectin-treated cells were examined, using an Act-D chase experiment. JWZ cells were stimulated with ivermectin for $24 \mathrm{~h}$ to induce $M d r 1$ mRNA expression, after which the transcription inhibitor Act-D was added in the presence of ivermectin for another $24 \mathrm{~h}$. Steady-state levels of Mdr1a and $M d r 1 b$ mRNA were determined at various time points after adding Act-D. There was a significantly slower rate of decline for ivermectin-treated cells versus control (Fig. 6). The half-life of Mdr1a and Mdr1b mRNA under control conditions were $8.6 \mathrm{~h}$
(Fig. 6A) and $10.4 \mathrm{~h}$ (Fig. 6B), respectively. By contrast, in ivermectin-induced cells, Mdr1a and Mdr1b mRNA half-lives were $17.3 \mathrm{~h}$ (Fig. 6A) and $17.2 \mathrm{~h}$ (Fig. 6B), respectively. This twofold increase of the half-life of the P-gp mRNA demonstrates that ivermectin treatment leads to the stabilization of the P-gp mRNA. It has to be noted that the degradation profiles for TBP mRNA in untreated and ivermectin-treated cells were similar (data not shown). Taken together, these results clearly indicated that upregulation of Mdr1 mRNA following exposure to ivermectin occurs, at least partially, at post-transcriptional level through a specific increase in Mdr1 mRNA stability.

\section{Discussion}

Despite the well documented interactions of ivermectin, a commonly used anthelmintic, with P-gp, there is no data on a possible modulation of the expression of this transporter by ivermectin. We have used murine cultured hepatocytes to study the effects of short-term exposure to ivermectin on P-gp expression and function.

In this study, ivermectin was found to up-regulate the two mouse P-gp isoforms Mdr1a and Mdr1b gene expression in both a time- and dose-dependent manner, demonstrating the specificity of the ivermectin-induced effect. Mdr1 mRNA levels were rapidly
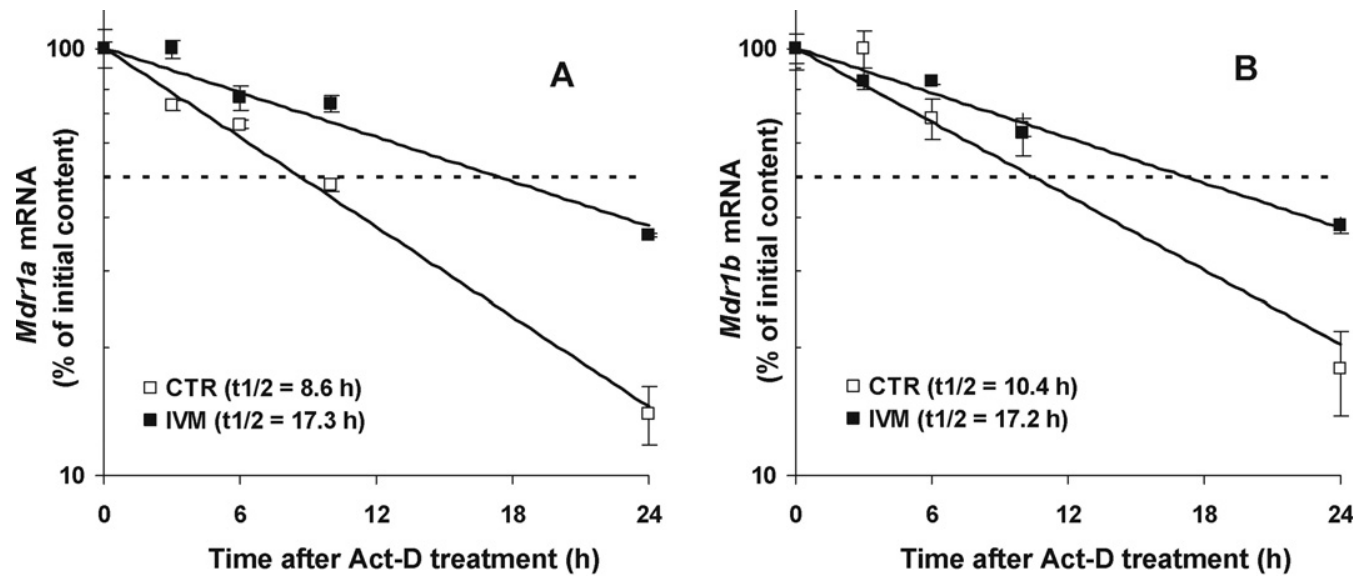

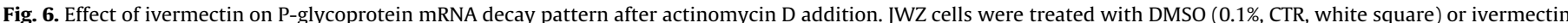

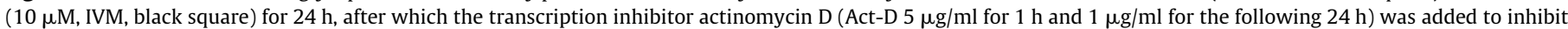

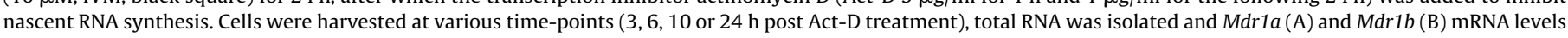

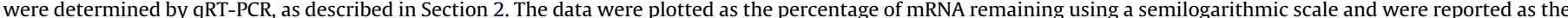

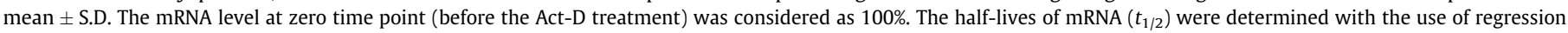
curves. 
induced, as early as $12 \mathrm{~h}$ after ivermectin addition for Mdr1a, with concentration as low as $0.5 \mu \mathrm{M}$, and the maximal effect for both $M d r 1 a$ and Mdr1b was observed $48 \mathrm{~h}$ after incubation. Furthermore, the induction of $M d r 1$ was found to be transient: the rapid increase in Mdr1 mRNA level reached a plateau at $24 \mathrm{~h}$ or $48 \mathrm{~h}$ and then decreased after longer exposure times, such as $72 \mathrm{~h}$. This kind of transient induction of MDR1 has already been described in hepatocytes after exposure to hepatocyte growth factor [41], or with two PXR activators, rifampicin and hyperforin [42]. The time- and concentration-dependent effect suggests that increased levels of P-gp in ivermectin-treated cells likely correspond to an acute induction in response to the anthelmintic drug. This is, to our knowledge, the first report showing that ivermectin is able to up-regulate the expression of this crucial transporter. Knowing that ivermectin is a good substrate of P-gp, our results are in agreement with the fact that, among other factors, the ability of drugs to interact with $A B C$ transporters can lead to overexpression of these proteins [15]. The expression of the MDR1 gene can be rapidly and transiently induced after a short-term exposure to a variety of xenobiotics in many cell lines, such as rodent cultured hepatocytes [3,43], human cancer cell lines $[44,45]$, but also after acute in vivo exposure of a tumor to cytotoxic chemotherapy [4]. Our results dealt with the expression of murine P-gp and it would be hazardous to extrapolate this conclusion to other species such as humans. Additional data are needed in order to explore the ability of ivermectin to regulate the P-gp gene expression in human hepatocytes. Nevertheless, it has been demonstrated that mdr1a and mdr1b gene expression in rodent and MDR1 in humans are, at least partially, controlled by the same negative regulatory element [46]. In addition, P-gp mRNA levels were increased in a dose- and time-dependent manner upon transient exposure to a variety of cytotoxic drugs including doxorubicin $[44,45]$ and daunorubicin $[45,47]$ in human cells but also in rodent cells $[3,48]$, demonstrating that similar regulatory effect of xenobiotic on P-gp expression in human and rodent cells can be observed.

The possible mechanisms involved in ivermectin up-regulation of $M d r 1 a$ and $M d r 1 b$ gene expression were investigated. The rapidity of the response upon ivermectin treatment excludes gene amplification, gene rearrangement or mutations and supports transcriptional activation or post-transcriptional regulation as the underlying mechanism.

We firstly examined the role of some transcription factors since transcriptional activation is the most common mechanism described for up-regulation of MDR1 gene expression, and several regulatory elements have been identified and characterized in the MDR1 promoter region. Since the nuclear receptors CAR and PXR are cellular sensors capable of responding to chemical exposure [49-51] and have been implicated in MDR1 regulation [37,52], we investigated their potential role in the ivermectin-induced modulation of P-gp. We therefore used mouse hepatocytes transiently overexpressing the functional mouse CAR or PXR. Similar patterns and extent of the dose-dependent modulations of P-gp induced by ivermectin were observed in CAR- or PXRoverexpressing cells and in control cells, which express CAR and PXR at a very low level. This strongly suggests that ivermectin may have CAR- and PXR-independent effects on gene expression. Furthermore, using bioluminescent cell lines expressing transcription factors, we have demonstrated that ivermectin was not a CAR, PXR or AhR ligand. In accordance with our results, it was previously shown that toxic insult increased MDR1 expression through CARindependent mechanisms [53]. However, the role of other transcription factors, including nuclear receptors, in the ivermectin-induced regulations cannot be discarded since number of them such as PPAR $\gamma$, as well as Nrf2, are described to be involved in efflux $A B C$ transporters transcriptional regulation $[8,37]$.
Besides transcriptional activation, post-transcriptional regulation at the level of mRNA stability was shown to be an important mechanism for P-gp overexpression in vitro [54] and in vivo $[10,55]$. In our study, Mdr1 mRNA decay was examined. mRNA half-life in untreated cells was found to be around $9 \mathrm{~h}$ which is in the range of values reported in the literature [35,56]. Interestingly, stability of Mdr1a and Mdr1b mRNA was markedly increased by ivermectin treatment, demonstrating that this drug reduced the degradation rate of Mdr1 mRNA thus contributing, at least in part, to the increase of P-gp gene expression. Interestingly, variety of drugs - such as cycloheximide [57], doxorubicin [58], vinblastine [58], colchicine [58], daunorubicin [47] or etoposide [47], were previously shown to induce $M D R 1$ gene expression in mammalian cells upon acute treatment, as short as a 24-h exposure, through enhanced mRNA stability rather than increased transcription. In further agreement with our results, atorvastatin, a P-gp substrate [59] and inhibitor [60], as ivermectin is, was able to induce P-gp mRNA expression [61]. More interestingly, regulation of MDR1 mRNA expression in human hepatocytes by atorvastatin was recently associated with a modulation in mRNA degradation [9]. The detailed mechanism that causes stabilization of P-gp mRNA in all of the above studies is currently unknown. The stability of a particular mRNA is partially controlled by specific interactions between its structural elements and trans-acting factors: mRNA binding proteins and some microRNAs. Recently, miRNAs, which contribute to post-transcriptional processing through 3 '-UTRinterference, have been involved in the regulation of $A B C B 1 \mathrm{mRNA}$ degradation $[62,63]$. Since several compounds have been shown to influence P-gp mRNA stability, it is reasonable to think that ivermectin may interact with a putative trans-acting stabilizing factor which is activated upon drug exposure, resulting in increased mRNA stability. However, the mRNA stabilizing mechanism which is responsible for the differential stability of P-gp mRNA in ivermectin-treated cells versus untreated cells remains to be elucidated.

In our conditions, when JWZ hepatocytes were exposed to $10 \mu \mathrm{M}$ ivermectin, Mdr1 mRNA level was increased up to 2.5-fold, due to a twofold increase in Mdr1 mRNA half-life, compared with untreated cells. It is now recognized that a two to fourfold fluctuation in mRNA half-life can have significant effects on mRNA and protein abundance [64]. Therefore, to investigate whether the induction of the P-gp mRNA level by ivermectin was reflected at the protein and transport activity level, an assay previously used to screen for P-gp-drug interactions [29] was performed. When cells were treated with $10 \mu \mathrm{M}$ ivermectin for $48 \mathrm{~h}$, conditions which caused a 2.5-fold increase in Mdr1 gene expression, the P-gp transport function was increased by more than $30 \%$. Consistently with our observation, an important correlation between P-gp modulation at the level of mRNA and the transport activity $[3,65,66]$, but also between P-gp protein levels and efflux activity following treatment with various drugs [67] has been reported. Interestingly, many compounds defined as P-gp substrates acted to induce P-gp gene expression and activity, but rarely displayed an inhibitory activity on the transporter [61]. Our results demonstrate that ivermectin, a competitive substrate displaying both substrate and inhibitory activity, was also able to up-regulated mRNA expression and consequently transport activity of the P-gp.

P-gp is expressed in multiple key organs in drug disposition such as small intestine, blood-brain barrier, kidney and liver and it is well established that induction of the P-gp activity can cause reduced drugs biodisposition and decreased therapeutic efficacy [68]. It was recently shown that even moderate increases in the expression of Mdr1 genes are sufficient to cause doxorubicin resistance in vivo [69], suggesting a possible impact on the pharmaco- and toxicokinetic of many drugs and endogenous P-gp substrates. The potential involvement of ivermectin in 
P-gp-mediated drug-drug interactions when administered with other drugs that are P-gp substrates should therefore be taken into account in human and veterinary therapy. Furthermore, since ivermectin disposition in host is mainly controlled by P-gp efflux at the intestinal [11] and hepatic level [12,13,70], up-regulation of its expression may contribute to the autoinduction of ivermectin elimination, resulting in a decrease of the body disposition and the intracellular levels of this anthelmintic agent in the host organism. This transport regulation may be considered as a first step in lowering the drug disposition and therefore drug efficacy. Acquired resistance to ivermectin is becoming a major clinical concern in the prevention/treatment of parasites and even though the factors responsible for the development of resistance to antiparasitic compounds are not perfectly understood, one of them is the exposure of parasites to subtherapeutic drug concentrations [71]. Therefore, this study offers insight into the potential for resistance development through modulation of ivermectin pharmacokinetic in the mammalian host. Furthermore, P-gp homologs are thought to play an important role in the resistance of nematode parasites against MLs [21], and data from the literature suggests that induction of P-gp expression in response to ivermectin treatment may also exist in nematodes. Indeed, P-gp homologs were shown to be overexpressed in ivermectin-resistant worms such as Haemonchus contortus [22] and Caenorhabditis elegans [23], and after exposure of the sea lice Lepeophtheirus salmonis to the ML emamectin [72]. Up-regulation of these proteins would serve to eliminate MLs from the parasite, limiting the accumulation of a toxic concentration at the target receptors, therefore offering protection of the parasite. Interestingly, multidrug resistance phenotype has been associated to an overexpression of some P-gp homologs through post-transcriptional regulation, including increase in mRNA stability in Bacillus subtilis [73], but also in the protozoan parasites Entamoeba histolytica [74]. Altogether, these data demonstrate that exposure to MLs, ivermectin in particular, potently modulates P-gps in both mammals and parasites and that partial similarities in the mechanisms of $\mathrm{ABC}$ efflux transporters regulation may exist between mammals and parasites. The elucidation of the molecular mechanisms of overexpression of $A B C$ efflux transporters in nematodes could provide useful markers for monitoring MLs resistance and possible targets for intervention in drug resistant parasites.

In summary, this report demonstrates for the first time that acute ivermectin treatment induces P-gp gene expression and activity in mouse hepatocytes through post-transcriptional regulation affecting P-gp mRNA degradation. These results have significant clinical implications regarding alteration of drug disposition and drug-drug interactions in host and offer insight into the potential for emergence of multidrug resistance during anthelmintic treatment in parasites.

\section{Acknowledgments}

We gratefully acknowledge Abdel Boulahtouf and Virginie Bellet for reporter cell lines studies. We also thank Arnaud Polizzi (Integrative Toxicology and Metabolism, INRA UMR1331) for helpful advices in qPCR studies.

\section{References}

[1] Osei-Atweneboana MY, Awadzi K, Attah SK, Boakye DA, Gyapong JO, Prichard RK. Phenotypic evidence of emerging ivermectin resistance in Onchocerca volvulus. PLoS Negl Trop Dis 2011;5:e998.

[2] Schinkel AH, Jonker JW. Mammalian drug efflux transporters of the ATP binding cassette (ABC) family: an overview. Adv Drug Deliv Rev 2003;55:3-29.

[3] Chin KV, Chauhan SS, Pastan I, Gottesman MM. Regulation of mdr RNA levels in response to cytotoxic drugs in rodent cells. Cell Growth Differ 1990;1:361-5.
[4] Abolhoda A, Wilson AE, Ross H, Danenberg PV, Burt M, Scotto KW. Rapid activation of MDR1 gene expression in human metastatic sarcoma after in vivo exposure to doxorubicin. Clin Cancer Res 1999;5:3352-6.

[5] Maglich JM, Stoltz CM, Goodwin B, Hawkins-Brown D, Moore JT, Kliewer SA. Nuclear pregnane $\mathrm{x}$ receptor and constitutive androstane receptor regulate overlapping but distinct sets of genes involved in xenobiotic detoxification. Mol Pharmacol 2002;62:638-46.

[6] Synold TW, Dussault I, Forman BM. The orphan nuclear receptor SXR coordinately regulates drug metabolism and efflux. Nat Med 2001;7:584-90.

[7] Wei P, Zhang J, Dowhan DH, Han Y, Moore DD. Specific and overlapping functions of the nuclear hormone receptors CAR and PXR in xenobiotic response. Pharmacogenomics J 2002;2:117-26.

[8] Maher JM, Cheng X, Slitt AL, Dieter MZ, Klaassen CD. Induction of the multidrug resistance-associated protein family of transporters by chemical activators of receptor-mediated pathways in mouse liver. Drug Metab Dispos 2005;33: 956-62.

[9] Rodrigues AC, Curi R, Hirata MH, Hirata RD. Decreased ABCB1 mRNA expression induced by atorvastatin results from enhanced mRNA degradation in HepG2 cells. Eur J Pharm Sci 2009;37:486-91.

[10] Lee CH, Bradley G, Ling V. Increased P-glycoprotein messenger RNA stability in rat liver tumors in vivo. J Cell Physiol 1998;177:1-12.

[11] Kiki-Mvouaka S, Menez C, Borin C, Lyazrhi F, Foucaud-Vignault M, Dupuy J, et al. Role of P-glycoprotein in the disposition of macrocyclic lactones: a comparison between ivermectin, eprinomectin, and moxidectin in mice. Drug Metab Dispos 2010;38:573-80.

[12] Kwei GY, Alvaro RF, Chen Q, Jenkins HJ, Hop CE, Keohane CA, et al. Disposition of ivermectin and cyclosporin A in CF-1 mice deficient in mdr1a P-glycoprotein. Drug Metab Dispos 1999;27:581-7.

[13] Schinkel AH, Smit JJ, van Tellingen O, Beijnen JH, Wagenaar E, van Deemter L et al. Disruption of the mouse mdr1a P-glycoprotein gene leads to a deficiency in the blood-brain barrier and to increased sensitivity to drugs. Cell 1994;77: 491-502.

[14] Lespine A, Chanoit G, Bousquet-Melou A, Lallemand E, Bassissi FM, Alvinerie $\mathrm{M}$, et al. Contribution of lymphatic transport to the systemic exposure of orally administered moxidectin in conscious lymph duct-cannulated dogs. Eur J Pharm Sci 2006;27:37-43.

[15] Schrenk D, Baus PR, Ermel N, Klein C, Vorderstemann B, Kauffmann HM. Upregulation of transporters of the MRP family by drugs and toxins. Toxicol Lett 2001;120:51-7.

[16] Lespine A, Martin S, Dupuy J, Roulet A, Pineau T, Orlowski S, et al. Interaction of macrocyclic lactones with P-glycoprotein: structure-affinity relationship. Eur J Pharm Sci 2007;30:84-94.

[17] Didier A, Loor F. The abamectin derivative ivermectin is a potent P-glycoprotein inhibitor. Anticancer Drugs 1996:7:745-51.

[18] Skalova L, Szotakova B, Machala M, Neca J, Soucek P, Havlasova J, et al. Effect of ivermectin on activities of cytochrome P450 isoenzymes in mouflon (Ovis musimon) and fallow deer (Dama dama). Chem Biol Interact 2001;137: 155-67.

[19] Skalova L, Szotakova B, Machala M, Neca J, Lamka J, Duchacek L, et al. Effect of ivermectin on induction of cytochromes P450 in male rats. Chem Papers 2000;54:249-53.

[20] Okey AB. Enzyme induction in the cytochrome P-450 system. Pharmacol Ther 1990;45:241-98.

[21] Prichard RK, Roulet A. ABC transporters and beta-tubulin in macrocyclic lactone resistance: prospects for marker development. Parasitology 2007;134: $1123-32$.

[22] Xu M, Molento M, Blackhall W, Ribeiro P, Beech R, Prichard R. Ivermectin resistance in nematodes may be caused by alteration of P-glycoprotein homolog. Mol Biochem Parasitol 1998;91:327-35.

[23] James CE, Davey MW. Increased expression of $A B C$ transport proteins is associated with ivermectin resistance in the model nematode Caenorhabditis elegans. Int J Parasitol 2009;39:213-20.

[24] Nishimura M, Koeda A, Suzuki E, Kawano Y, Nakayama M, Satoh T, et al. Regulation of mRNA expression of MDR1, MRP1, MRP2 and MRP3 by prototypical microsomal enzyme inducers in primary cultures of human and rat hepatocytes. Drug Metab Pharmacokinet 2006;21:297-307.

[25] Sueyoshi T, Kawamoto T, Zelko I, Honkakoski P, Negishi M. The repressed nuclear receptor CAR responds to phenobarbital in activating the human CYP2B6 gene. J Biol Chem 1999;274:6043-6.

[26] Xiong H, Yoshinari K, Brouwer KL, Negishi M. Role of constitutive androstane receptor in the in vivo induction of Mrp3 and CYP2B1/2 by phenobarbital. Drug Metab Dispos 2002;30:918-23.

[27] Tien ES, Gray JP, Peters JM, Vanden Heuvel JP. Comprehensive gene expression analysis of peroxisome proliferator-treated immortalized hepatocytes: identification of peroxisome proliferator-activated receptor alpha-dependent growth regulatory genes. Cancer Res 2003;63:5767-80.

[28] Eveillard A, Mselli-Lakhal L, Mogha A, Lasserre F, Polizzi A, Pascussi JM, et al. Di-(2-ethylhexyl)-phthalate (DEHP) activates the constitutive androstane receptor (CAR): a novel signalling pathway sensitive to phthalates. Biochem Pharmacol 2009;77:1735-46.

[29] Hollo Z, Homolya L, Davis CW, Sarkadi B. Calcein accumulation as a fluorometric functional assay of the multidrug transporter. Biochim Biophys Acta 1994;1191:384-8.

[30] Pascussi JM, Robert A, Nguyen M, Walrant-Debray O, Garabedian M, Martin P, et al. Possible involvement of pregnane X receptor-enhanced CYP24 expression in drug-induced osteomalacia. J Clin Invest 2005;115:177-86. 
[31] Seimandi M, Lemaire G, Pillon A, Perrin A, Carlavan I, Voegel JJ, et al. Differential responses of PPARalpha, PPARdelta, and PPARgamma reporter cell lines to selective PPAR synthetic ligands. Anal Biochem 2005;344:8-15.

[32] Lemaire G, Mnif W, Pascussi JM, Pillon A, Rabenoelina F, Fenet H, et al. Identification of new human pregnane $X$ receptor ligands among pesticides using a stable reporter cell system. Toxicol Sci 2006;91:501-9.

[33] Lemaire G, Benod C, Nahoum V, Pillon A, Boussioux AM, Guichou JF, et al. Discovery of a highly active ligand of human pregnane $x$ receptor: a case study from pharmacophore modeling and virtual screening to "in vivo" biological activity. Mol Pharmacol 2007;72:572-81.

[34] Dagnino S, Gomez E, Picot B, Cavailles V, Casellas C, Balaguer P, et al. Estrogenic and AhR activities in dissolved phase and suspended solids from wastewater treatment plants. Sci Total Environ 2010;408:2608-15.

[35] Muller C, Goubin F, Ferrandis E, Cornil-Scharwtz I, Bailly JD, Bordier C, et al. Evidence for transcriptional control of human mdr1 gene expression by verapamil in multidrug-resistant leukemic cells. Mol Pharmacol 1995;47:51-6.

[36] Mathieu MC, Lapierre I, Brault K, Raymond M. Aromatic hydrocarbon receptor (AhR).AhR nuclear translocator- and p53-mediated induction of the murine multidrug resistance mdr1 gene by 3-methylcholanthrene and benzo(a)pyrene in hepatoma cells. J Biol Chem 2001;276:4819-27.

[37] Burk O, Arnold KA, Geick A, Tegude H, Eichelbaum M. A role for constitutive androstane receptor in the regulation of human intestinal MDR1 expression. Biol Chem 2005;386:503-13.

[38] Honkakoski P, Zelko I, Sueyoshi T, Negishi M. The nuclear orphan receptor CAR-retinoid $X$ receptor heterodimer activates the phenobarbital-responsive enhancer module of the CYP2B gene. Mol Cell Biol 1998;18:5652-8.

[39] Lehmann JM, McKee DD, Watson MA, Willson TM, Moore JT, Kliewer SA. The human orphan nuclear receptor PXR is activated by compounds that regulate CYP3A4 gene expression and cause drug interactions. J Clin Invest 1998;102: 1016-23.

[40] Balaguer P, Boussioux AM, Demirpence E, Nicolas JC. Reporter cell lines are useful tools for monitoring biological activity of nuclear receptor ligands. Luminescence 2001;16:153-8.

[41] Le Vee M, Lecureur V, Moreau A, Stieger B, Fardel O. Differential regulation of drug transporter expression by hepatocyte growth factor in primary human hepatocytes. Drug Metab Dispos 2009;37:2228-35.

[42] Ott M, Fricker G, Bauer B. Pregnane X receptor (PXR) regulates P-glycoprotein at the blood-brain barrier: functional similarities between pig and human PXR. J Pharmacol Exp Ther 2009;329:141-9.

[43] Schrenk D, Michalke A, Gant TW, Brown PC, Silverman JA, Thorgeirsson SS. Multidrug resistance gene expression in rodents and rodent hepatocytes treated with mitoxantrone. Biochem Pharmacol 1996;52:1453-60.

[44] Chaudhary PM, Roninson IB. Induction of multidrug resistance in human cells by transient exposure to different chemotherapeutic drugs. J Natl Cancer Inst 1993;85:632-9.

[45] Hu XF, Slater A, Wall DM, Kantharidis P, Parkin JD, Cowman A, et al. Rapid upregulation of mdr1 expression by anthracyclines in a classical multidrugresistant cell line. Br J Cancer 1995;71:931-6.

[46] Gant TW, Silverman JA, Thorgeirsson SS. Regulation of P-glycoprotein gene expression in hepatocyte cultures and liver cell lines by a trans-acting transcriptional repressor. Nucleic Acids Res 1992;20:2841-6.

[47] Baker EK, Johnstone RW, Zalcberg JR, El-Osta A. Epigenetic changes to the MDR1 locus in response to chemotherapeutic drugs. Oncogene 2005;24:8061-75.

[48] Fardel O, Lecureur V, Daval S, Corlu A, Guillouzo A. Up-regulation of Pglycoprotein expression in rat liver cells by acute doxorubicin treatment. Eur J Biochem 1997;246:186-92.

[49] Timsit YE, Negishi M. CAR and PXR: the xenobiotic-sensing receptors. Steroids 2007;72:231-46.

[50] Tolson AH, Wang H. Regulation of drug-metabolizing enzymes by xenobiotic receptors: PXR and CAR. Adv Drug Deliv Rev 2010;62:1238-49.

[51] Xie W, Barwick JL, Simon CM, Pierce AM, Safe S, Blumberg B, et al. Reciprocal activation of xenobiotic response genes by nuclear receptors SXR/PXR and CAR. Genes Dev 2000;14:3014-23.

[52] Kota BP, Tran VH, Allen J, Bebawy M, Roufogalis BD. Characterization of PXR mediated P-glycoprotein regulation in intestinal LS174T cells. Pharmacol Res 2010;62:426-31.
[53] Haslam IS, Jones K, Coleman T, Simmons NL. Rifampin and digoxin induction of MDR1 expression and function in human intestinal (T84) epithelial cells. Br J Pharmacol 2008;154:246-55.

[54] Lee CH, Bradley G, Ling V. Overexpression of the class II P-glycoprotein gene in primary rat hepatocyte culture: evidence for increased mRNA stability. Cell Growth Differ 1995;6:347-54.

[55] Kren BT, Trembley JH, Steer CJ. Alterations in mRNA stability during rat liver regeneration. Am J Physiol 1996;270:G763-77.

[56] Prokipcak RD, Raouf A, Lee C. The AU-rich $3^{\prime}$ untranslated region of human MDR1 mRNA is an inefficient mRNA destabilizer. Biochem Biophys Res Commun 1999;261:627-34.

[57] Lee $\mathrm{CH}$. Induction of P-glycoprotein mRNA transcripts by cycloheximide in animal tissues: evidence that class I Pgp is transcriptionally regulated whereas class II Pgp is post-transcriptionally regulated. Mol Cell Biochem 2001;216: 103-10.

[58] Yague E, Armesilla AL, Harrison G, Elliott J, Sardini A, Higgins CF, et al. Pglycoprotein (MDR1) expression in leukemic cells is regulated at two distinct steps, mRNA stabilization and translational initiation. J Biol Chem 2003;278: 10344-52.

[59] Hochman JH, Pudvah N, Qiu J, Yamazaki M, Tang C, Lin JH, et al. Interactions of human P-glycoprotein with simvastatin, simvastatin acid, and atorvastatin. Pharm Res 2004;21:1686-91.

[60] Boyd RA, Stern RH, Stewart BH, Wu X, Reyner EL, Zegarac EA, et al. Atorvastatin coadministration may increase digoxin concentrations by inhibition of intestinal P-glycoprotein-mediated secretion. J Clin Pharmacol 2000;40:91-8.

[61] Haslam IS, Jones K, Coleman T, Simmons NL. Induction of P-glycoprotein expression and function in human intestinal epithelial cells (T84). Biochem Pharmacol 2008;76:850-61.

[62] Kovalchuk O, Filkowski J, Meservy J, Ilnytskyy Y, Tryndyak VP, Chekhun VF, et al. Involvement of microRNA-451 in resistance of the MCF-7 breast cancer cells to chemotherapeutic drug doxorubicin. Mol Cancer Ther 2008;7:2152-9.

[63] Zhu H, Wu H, Liu X, Evans BR, Medina DJ, Liu CG, et al. Role of MicroRNA miR27a and miR-451 in the regulation of MDR1/P-glycoprotein expression in human cancer cells. Biochem Pharmacol 2008;76:582-8.

[64] Ross J. mRNA stability in mammalian cells. Microbiol Rev 1995;59:423-50.

[65] Schrenk D, Gant TW, Michalke A, Orzechowski A, Silverman JA, Battula N, et al. Metabolic activation of 2-acetylaminofluorene is required for induction of multidrug resistance gene expression in rat liver cells. Carcinogenesis 1994;15: 2541-6.

[66] Cermanova J, Fuksa L, Brcakova E, Hroch M, Kucera O, Kolouchova G, et al. Upregulation of renal Mdr1 and Mrp2 transporters during amiodarone pretreatment in rats. Pharmacol Res 2010;61:129-35.

[67] Abuznait AH, Patrick SG, Kaddoumi A. Exposure of LS-180 cells to drugs of diverse physicochemical and therapeutic properties up-regulates P-glycoprotein expression and activity. J Pharm Pharm Sci 2011;14:236-48.

[68] Glaeser H. Importance of P-glycoprotein for drug-drug interactions. Handb Exp Pharmacol 2011;1:285-97.

[69] Pajic M, Iyer JK, Kersbergen A, van der Burg E, Nygren AO, Jonkers J, et al. Moderate increase in Mdr1a/1b expression causes in vivo resistance to doxorubicin in a mouse model for hereditary breast cancer. Cancer Res 2009;69: 6396-404.

[70] Geyer J, Gavrilova O, Petzinger E. Brain penetration of ivermectin and selamectin in mdr1a,b P-glycoprotein- and bcrp-deficient knockout mice. J Vet Pharmacol Ther 2009;32:87-96.

[71] Van Zeveren AM, Casaert S, Alvinerie M, Geldhof P, Claerebout E, Vercruysse J. Experimental selection for ivermectin resistance in Ostertagia ostertagi in cattle. Vet Parasitol 2007;150:104-10.

[72] Tribble ND, Burka JF, Kibenge FS. Evidence for changes in the transcription levels of two putative P-glycoprotein genes in sea lice (Lepeophtheirus salmonis) in response to emamectin benzoate exposure. Mol Biochem Parasitol 2007; 153:59-65.

[73] Ohki R, Tateno K. Increased stability of bmr3 mRNA results in a multidrugresistant phenotype in Bacillus subtilis. J Bacteriol 2004;186:7450-5.

[74] Lopez-Camarillo C, Luna-Arias JP, Marchat LA, Orozco E. EhPgp5 mRNA stability is a regulatory event in the Entamoeba histolytica multidrug resistance phenotype. J Biol Chem 2003;278:11273-80. 